\title{
Dlaczego u pacjenta $z$ chorobą wieńcową wybieramy bisoprolol?
}

\author{
prof. dr hab. n. med. Beata Wożakowska-Kapłon
}

I Klinika Kardiologii i Elektroterapii, Wydział Lekarski i Nauk o Zdrowiu, Uniwersytet Jana Kochanowskiego, Kielce

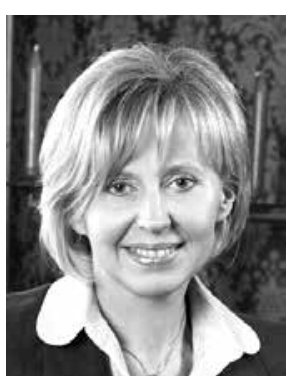

Uzyskanie optymalnej częstości rytmu serca stanowi jeden $z$ głównych celów terapii kardiologicznej. Zwiększona częstość rytmu serca w spoczynku jest silnym niezależnym czynnikiem ryzyka niepomyślnego rokowania u pacjentów ze stabilną chorobą wieńcową.

Leki $\beta$-adrenolityczne stanowią podstawową grupę preparatów stosowanych w farmakologicznej kontroli częstości rytmu i pierwszą, w przypadku której na tak szeroką skalę potwierdzono znaczenie terapeutycznego zwalniania pracy serca w celu poprawy rokowania chorych [1]. Mechanizm dobroczynnego wpływu optymalizacji częstości rytmu wyczerpująco przedstawił autor komentowanej pracy — dr n. med. Marcin Barylski, Prezes Elekt Sekcji Farmakoterapii Sercowo-Naczyniowej Polskiego Towarzystwa Kardiologicznego [2]. Wszystkie obowiązujące dokumenty dotyczące postępowania u pacjentów z chorobą niedokrwienną serca, ostrymi zespołami wieńcowymi czy u chorych po rewaskularyzacji odnoszą się do terapii $\beta$-adrenolitykiem, chociaż różna jest klasa zaleceń i poziom dowodów, ponieważ przy zastosowaniu tych leków w zależności od sytuacji klinicznej oczekuje się poprawy rokowania i/lub złagodzenia objawów choroby wieńcowej [3-6]. Leki $\beta$-adrenolityczne hamują wpływ krążących katecholamin na miokardium, ograniczają zużycie tlenu przez mięsień sercowy poprzez zmniejszenie częstości rytmu serca, ciśnienia tętniczego i kurczliwości. Korzystnym efektem działania $\beta$-adrenolityków jest również redukcja aktywności reninowej osocza [7].

Wśród kilkunastu dostępnych w Polsce preparatów leków $\beta$-adrenolitycznych cząsteczką najczęściej wybieraną przez lekarzy, ze stale rosnącą sprzedażą, jest bisopropol. Dlaczego w chorobie wieńcowej nasz wybór pada na bisoprolol?

Przede wszystkim ze względu na właściwości leku idealnie wpisujące się w potrzeby pacjenta z chorobą niedokrwienną serca. Bisoprolol jest $\beta$-adrenolitykiem wysoce selektywnym w stosunku do receptorów "sercowych" $\beta 1$. Kardioselektywność bywa również szczególnie korzystna w przypadku współistnienia z chorobą wieńcową zaburzeń lipidowych, cukrzycy, choroby naczyń obwodowych, choroby obturacyjnej płuc czy też zaburzeń funkcji seksualnych. Inne cechy bisoprololu (szczegółowo omówione w komentowanym artykule) to pośrednia lipofilność leku, efektywne wchłanianie, niski efekt pierwszego przejścia przez wątrobę, wysoka biodostępność, długi okres półtrwania i wysoka wartość wskaźnika trough/peak oznaczająca całodobową skuteczność i możliwość stosowania leku raz na dobę. Korzystne efekty farmakokinetyczne bisoprololu wzmacnia fakt braku interakcji lekowych i zrównoważony klirens wątrobowo-nerkowy, dzięki czemu nie ma konieczności modyfikacji dawki przy niewydolności tych narządów. Mała zmienność międzyosobnicza i wewnątrzosobnicza gwarantują stabilność terapii. Bisoprolol nie ma właściwości wazodylatacyjnych, co w przypadku osiągania celów terapii choroby wieńcowej (tj. obniżania częstości rytmu serca do 55-60 uderzeń/min) jest niewątpliwą zaletą tego preparatu.

Z chorobą wieńcową często współistnieją nadciśnienie tętnicze, zaburzenia rytmu czy niewydolność serca. W wymienionych wyżej sytuacjach klinicznych bisoprolol wykazuje korzystne działanie udokumentowane wynikami wieloośrodkowych badań klinicznych.

Przy powszechnym stosowaniu $\beta$-adrenolityków u pacjentów z chorobą niedokrwienną serca, zarówno w warunkach szpitalnych, jak i ambulatoryjnych, należy pamiętać o istniejących ograniczeniach dla tej grupy leków. Bezwzględnych przeciwwskazań do zastosowania bisoprololu, podobnie jak w przypadku całej grupy $\beta$-adrenolityków, jest niewiele — należą do nich znaczna bradykardia oraz zaawansowane zaburzenia przewodzenia przedsionkowo-komorowego. Mimo że zwolnienie częstości rytmu serca poniżej 60 uderzeń na minutę jest ważnym celem leczenia stabilnej choroby wieńcowej, u pacjentów, u których początkowo stwierdza się wolną czynność serca, należy unikać stosowania leków zwalniających rytm serca ( $\beta$-adrenolityków, iwabradyny, antagonistów wapnia) lub stosować je ostrożnie, w razie potrzeby rozpoczynając ich podawanie od bardzo małych dawek. Również u chorych z zawałem serca obarczonych ryzykiem wystąpienia wstrząsu kardiogennego (wiek > 70 lat, częstość rytmu serca > 110 uderzeń/min, skurczowe ciśnienie tętnicze < 120 mm Hg) należy unikać wczesnego podawania $\beta$-adrenolityków, jeśli funkcja lewej komory jest nieznana. 
Ponadto $\beta$-adrenolityków nie wolno stosować u pacjentów z podejrzeniem lub potwierdzoną dławicą naczynioskurczową lub gdy objawy dławicowe prawdopodobnie wynikają ze skurczu tętnicy wieńcowej, np. u chorego po zażyciu kokainy, ponieważ $\beta$-adrenolityki mogą sprzyjać reakcji naczynioskurczowej. Wczesne rozpoczęcie leczenia $\beta$-adrenolitykiem w początkowej fazie zawału serca jest zalecane u pacjentów z utrzymującymi się objawami niedokrwienia i bez istniejących przeciwwskazań, takich jak objawy niewydolności serca $w \geq$ III klasie Killipa.

W prezentowanej pracy zostały opisane przypadki dwojga pacjentów, u których w przebiegu choroby niedokrwiennej serca prawidłowo i zgodnie z wytycznymi zastosowano bisoprolol. Przedstawiono typowe, „z życia wzięte” sylwetki chorych i najczęściej stosowane schematy postępowania diagnostycznego. W przypadku pierwszego chorego były to: bóle w klatce piersiowej, dodatni test wysiłkowy, koronarografia. Czy zawsze jednak jest to optymalny algorytm? Przeanalizujmy wspólnie postępowanie u pierwszego chorego w kontekście obowiązujących wytycznych [5]. U 54-letniego mężczyzny z typowymi bólami w klatce piersiowej prawdopodobieństwo choroby wieńcowej przed testem oceniamy na 66-85\%. $\cup$ takich chorych początkowym badaniem powinno być obrazowanie obciążeniowe (np. echokardiografia obciążeniowa), któremu, zamiast diagnostycznej próbie wysiłkowej, powinien zostać poddany opisany pacjent. Głęboki sens tego zalecenia odkrywamy, analizując wynik angiografii tętnic wieńcowych u tego chorego. Otóż, gdybyśmy dysponowali wynikiem wspomnianej próby obciążeniowej istotność 50-procentowego zwężenia w początkowym odcinku prawej tętnicy wieńcowej zostałaby zweryfikowana już w trakcie wykonywania koronarografii. Lekarz hemodynamista zdecydowałby o angioplastyce tętnicy w przypadku istotnego czynnościowego (a nie anatomicznego) zwężenia z udokumentowanym niedokrwieniem. W wytycznych mówi się co prawda o ponad 50-procentowym zwężeniu, ale między $50 \%$ a $51 \%$ jest rzeczywiście granica ulotna [4]. Jak wiemy, w polskich warunkach wdrażanie takiego schematu postępowania diagnostycznego zalecanego w wytycznych nie jest zbyt częste zapewne ze względu na małą dostępność pracowni wykonujących obrazowe badania obciążeniowe. Dlatego też u opisanego chorego należałoby poznać cząstkową rezerwę przepływu w prawej tętnicy wieńcowej (FFR) i zapewne takiej oceny oczekiwałabym w trakcie przeprowadzanego badania angiograficznego. W przypadku wyniku FFR $<0,80$ u chorego niereagującego na leczenie zachowawcze należałoby wówczas jednocześnie wykonać angioplastykę zwężonego naczynia. Warunek braku reakcji na leczenie zachowawcze nakazywałby optymalizację farmakoterapii najlepiej jeszcze przed zaplanowaną koronarografią. Należy podkreślić, że angioplastykę w takich przypadkach przeprowadza się w celu zmniejszenia objawów, a nie przedłużenia życia. Nie znamy dalszych losów chorego i przyjmujemy, że optymalizacja farmakoterapii oraz prozdrowotna modyfikacja stylu życia doprowadziły do ustąpienia objawów. Niewątpliwie wdrożenie u chorego bisoprololu było trafną decyzją, podobnie jak pozostałych preparatów. Gdybym jednak mogła zasugerować jakieś zmiany w zastosowanym schemacie leczenia, to pewnie ramipril zastąpiłabym perindoprilem, inhibitorem o dłuższym okresie półtrwania i udokumentowanym korzystnym działaniu w stabilnej dławicy piersiowej (badanie EUROPA [8].

W opisie drugiego przypadku nie mamy wątpliwości, że natychmiastowa interwencja i udrożnienie dozawałowego naczynia było jedynym słusznym postępowaniem, jednak wątpliwości powstają, kiedy dowiadujemy się, jaki rodzaj stentu został implantowany do tętnicy. $U$ chorej należało zastosować stent pokrywany substancją antymitotyczną, stent najlepiej nowej generacji. Obowiązujące wytyczne dotyczące rewaskularyzacji jedynie w przypadkach wyjątkowych i uzasadnionych sytuacją kliniczną dopuszczają/zalecają zastosowanie stentu metalowego (np. u chorej ciężarnej). Kontynuując wątek obowiązujących zaleceń, u opisanej pacjentki klopidogrel powinien być zastosowany jedynie wówczas, jeżeli z jakichś względów (w naszej rzeczywistości najczęściej ekonomicznych) tikagrelor nie byłby dostępny. Terapia bisoprololem była wskazana i ściśle uzasadniona u przedstawionej pacjentki, u której występowała nie tylko choroba niedokrwienna serca w jej ostrej postaci, ale również nadciśnienie tętnicze i objawy niewydolności serca z łagodną dysfunkcją skurczową lewej komory. Prawdopodobnie gdyby to mnie przyszło ustalać postępowanie farmakologiczne u tej chorej, na zwiększenie dawki bisoprololu zdecydowałabym się nieco później, już w warunkach ambulatoryjnych. Dołączyłabym również eplerenon kosztem zmniejszenia dawki torasemidu, traktując ten ostatni bardziej w kontekście hipotensyjnym niż stabilizującym układ sercowo-naczyniowy. Uogólniając problem terapii $\beta$-adrenolitykami, na szczególne podkreślenie zasługuje konieczność potencjalizacji dawki — w tym wypadku bisoprololu — w sytuacji nieosiągania docelowej częstości rytmu serca (często niestety niewdrażana u pacjentów). Cenne jest, że wybrzmiało to w komentowanym artykule, podobnie jak fakt stosowania maksymalnych dobrze tolerowanych dawek statyn.

Oboje opisami przez dra Barylskiego pacjenci to chorzy z licznymi czynnikami ryzyka - nadciśnieniem tętniczym, dyslipidemią, nałogiem palenia tytoniu, nadwagą. W obu przypadkach stwierdzano występowanie przedwczesnej miażdżycy w rodzinie, co niestety — nieuświadomione należycie przez opisanych chorych - nie wpłynęło na wdrożenie zdrowego stylu życia, jeszcze zanim pojawiły się objawy choroby. Nasi pacjenci mają istotny problem nie tylko ze zdefiniowaniem schorzeń sercowo-naczyniowych występujących w najbliższej rodzinie, ale istniejących u nich klasycznych czynników ryzyka miażdżycy, takich jak palenie tytoniu, hipercholesterolemia czy nadciśnienie tętnicze. Stwierdzamy to wielokrotnie podczas zbierania wywiadu 
u osób hospitalizowanych z powodu choroby niedokrwiennej serca.

Reasumując, zachęcam Państwa do lektury artykułu „Bisoprolol w chorobie niedokrwiennej serca — przykłady zastosowania w praktyce klinicznej" — znakomitej minimonografii bisoprololu w kontekście choroby niedokrwiennej serca popartej interesującymi „nielukrowanymi” przypadkami klinicznymi.

\section{Konflikt interesów: nie zgłoszono}

\section{Piśmiennictwo}

1. Kasprzak JD, Stępińska J, Wożakowska-Kapłon B et al. Optymalna częstość rytmu serca - aktualny cel terapii kardiologicznej. Stanowisko grupy ekspertów Sekcji Farmakoterapii Sercowo-Naczyniowej Polskiego Towarzystwa Kardiologicznego. Kardiol Pol, 2012; 70: 1081-1094.

2. Barylski M. Bisoprolol w chorobie niedokrwiennej serca — przykłady zastosowania w praktyce klinicznej. Kardiol Pol, 2016; 74 (suppl. V): 63-70.

3. Steg PhG, James SK, Atar D et al. ESC Guidelines for the management of acute myocardial infarction in patients presenting with ST-segment elevation. Eur Heart J, 2012; 33: 2569-2619.
4. Kolh P, Windecker S, Alfonso S et al. 2014 ESC/EACTS Guidelines on myocardial revascularization. The Task Force on Myocardial Revascularization of the European Society of Cardiology (ESC) and the European Association for Cardio-Thoracic Surgery (EACTS). Eur Heart J, 2014; 35: 2541-2619.

5. Montalescot G, Sechtem U, Achenbach S et al. 2013 ESC guidelines on the management of stable coronary artery disease. The Task Force on the management of stable coronary artery disease of the European Society of Cardiology. Eur Heart J, 2014; 34: 2949-3003.

6. Roffi M, Patrono C, Collet JP et al. 2015 ESC Guidelines for the management of acute coronary syndromes in patients presenting without persistent ST-segment elevation: Task Force for the Management of Acute Coronary Syndromes in Patients Presenting without Persistent ST-Segment Elevation of the European Society of Cardiology (ESC). Eur Heart J, 2016; 37: 267-315.

7. Filipiak KJ, Grabowski M, Opolski G. Farmakologia kliniczna leków beta-adrenolitycznych. In: Grodzicki T, Januszewicz A, Opolski G eds. Leki beta-adrenolityczne w chorobach układu sercowo-naczyniowego. Via Medica, Gdańsk 2004.

8. The EURopean trial On reduction of cardiac events with Perindopril in stable coronary Artery disease Investigators Efficacy of perindopril in reduction of cardiovascular events among patients with stable coronary artery disease: randomised, double-blind, placebo-controlled, multicentre trial (the EUROPA study). Lancet, 2003; 362: 782-788. 